\title{
KINERJA DIAGRAM KONTROL W DAN DIAGRAM KONTROL G
}

\author{
M. Stivo Noya Van Delsen ${ }^{1}$, Mozart Winston Talakua ${ }^{2}$ \\ 1,2, Jurusan Matematika FMIPA UNPATTI \\ Jl. Ir. M. Putuhena, Kampus Unpatti, Poka-Ambon, Maluku \\ e-mail: ${ }^{1}$ marlonnvd@gmail.com, ${ }^{2}$ ocat1615@yahoo.com
}

\begin{abstract}
ABSTRAK
Pengontrolan terhadap variabilitas proses merupakan salah satu hal yang sangat penting dalam bidang industri. Sehingga, saat ini dikembangkan diagram kontrol yang khusus untuk memonitor variabilitas proses. Diagram kontrol multivariat yang digunakan untuk memonitor variabilitas proses antara lain diagram diagram kontrol $\mathrm{W}$ dan diagram kontrol G. Salah satu cara yang dapat digunakan untuk melihat kinerja diagram kontrol adalah dengan menggunakan Average Run Length (ARL). Sehingga pada penelitian ini akan dilihat kinerja dari diagram kontrol $\mathrm{W}$ dan diagram kontrol G, kemudian membandingkan kinerja diagram kontrol $W$ dan $G$ dengan menggunakan ARL. Hasil dari ARL menunjukkan bahwa nilai ARL yang diperoleh diagram kontrol G lebih kecil dari diagram kontrol W. Berdasarkan hasil tersebut dapat disimpulkan bahwa kinerja diagram kontrol G lebih baik dibandingkan dengan diagram kontrol $\mathrm{W}$, namun untuk pergeseran varian yang besar diagram kontrol W dapat digunakan sebagai pendamping diagram kontrol $\mathrm{G}$.

Kata Kunci : Average Run Length, Diagram Kontrol G, Diagram Kontrol W
\end{abstract}

\section{PERFORMANCE OF W CONTROL CHART AND G CONTROL CHART}

\begin{abstract}
Monitoring of variability process is the important in industry. So, today has been developed multivariate control charts which are usefull for monitoring vaiabilty process. Multivariate control charts used to monitor variability process, among others $\mathrm{W}$ control chart and $\mathrm{G}$ control chart. Performance of control charts can be seen with Average Run Length (ARL). So in this study will be seen the performance of the $\mathrm{W}$ control chart and $\mathrm{G}$ control chart, and then compare the performance $\mathrm{W}$ control chart and $\mathrm{G}$ control chart by ARL. Result of the ARL shows that the value's G control chart is smaller than the W control chart. Based on the results can be conclude that the performance of $\mathrm{G}$ control chart is better than the W control chart, but for the large of variance shift the $\mathrm{W}$ control chart can be used with $\mathrm{G}$ control chart as companion.
\end{abstract}

Keywords : Average run length, control chart G, control chart W

\section{Pendahuluan}

Penerapan ilmu statistika hingga saat ini sangat berkembang pesat. Salah satu bidang yang merasakan dampak tersebut adalah bidang industri. Penerapan statistika dalam bidang industri lebih dikenal dengan statistika industri. Metode yang dapat digunakan dalam statistika industri adalah Statistical Process Control (SPC). SPC digunakan untuk menganalisis dan memperbaiki suatu proses dengan menggunakan diagram kontrol (Control Chart).

Diagram kontrol adalah sebuah grafik yang memberi gambaran tentang perilaku sebuah proses. Berdasarkan banyaknya karakteristik kualitas yang diamati, diagram kontrol terdiri dari diagram kontrol univariat dan diagram kontrol multivariat. Namun dalam mengamati atau memonitor perilaku sebuah proses banyaknya karakteristik kualitas yang digunakan lebih dari satu, ini mengakibatkan diagram kontrol multivariat lebih sering digunakan dibandingkan dengan diagram kontrol univariat. Selain itu, dalam memonitor proses dapat dilakukan melalui memonitor mean proses dan memonitor variabilitas proses [6]. 
Hingga saat ini, diagram kontrol multivariat untuk memonitor variabilitas proses terus berkembang. Diagram kontrol ini pertama kali dikembangkan oleh Alt (1985) yang mengembangkan diagram kontrol W berdasarkan likelihood ratio test $\mathrm{W}$ dan diagram kontrol $|\mathrm{S}|$ yang berdasar pada sample generalized variance. Kemudian pada tahun 2002 dikembangkan diagram kontrol G yang diperoleh dari perluasan konsep statistik $\mathrm{G}$ oleh Levinson, Holmes dan Mergen. Pada tahun 2005, Djauhari mengembangkan diagram kotrol $|\mathrm{S}|$ menjadi diagram kotrol improved genralized sample atau diagram kontrol Impreved $|\mathrm{S}|$. Setelah itu Sindelar (2007) mengembangkan diagram kontrol berdasarkan matriks korelasi yang dikenal dengan diagram kontrol $\mathrm{W}_{\mathrm{R}}$.

Dalam perkembangannya kinerja diagram kontrol juga selalu menjadi perhatian khusus. Untuk melihat kinerja suatu dagram kontrol dapat menggunakan Average Run Length (ARL). Rakhmawati (2011) menggunakan nilai ARL untuk membandingkan kinerja diagram kontrol $\mathrm{W}$ dan diagram kontrol $\mathrm{W}_{\mathrm{R}}$. Pada peneltian tersebut dihasilkan bahwa diagram kontrol W mempunyai kinerja yang lebih baik dari diagram kontrol $\mathrm{W}_{\mathrm{R}}$. Kemudian pada tahun 2013, Noya Van Delsen dan Mashuri menggunakan nilai ARL untuk membandingkan diagram kontrol $\mathrm{G}$ dengan diagram kontrol $|\mathrm{S}|$, yang menghasilkan bahwa kinerja diagram kontrol $\mathrm{G}$ lebih baik dibanding diagram kontrol $|\mathrm{S}|$. Menindaklanjuti kedua penelitian tersebut, maka penelitian ini bertujuan untuk membandingkan kinerja diagram kontrol $\mathrm{G}$ dan diagram kontrol $\mathrm{W}$ dengan menggunakan ARL.

\section{Tinjauan Pustaka}

Tahun 1985 diketahui sebagai awal mula munculnya diagram kontrol multivariat untuk memonitor variabilitas proses oleh Alt dan Smith. Alt dan Smith mengembangkan diagram kontrol berdasarkan statistik Likelihood Ratio Test dan Sample Generalized Variance, atau yang lebih dikenal dengan diagram kontrol W dan diagram kontorl |S|. Diagram kontrol berikut dikembangkan berdasarkan pada statistik G oleh Levinson, Holmes dan Mergen (2002). Kemudian Djauhari (2005) mengembangkan diagram kontrol |S|, yang dikenal dengan diagram kontrol Improved $|\mathrm{S}|$ dan Sindelar (2007) mengembangkan diagram kontrol berdasarkan matriks korelasi atau diagram kontrol $\mathrm{W}_{\mathrm{R}}$.

Menindaklanjuti penelitian Sindelar, Rakhmawati (2011) membandingkan kinerja diagram kontrol W dengan kinerja diagram kontrol $\mathrm{W}_{\mathrm{R}}$. Kemudian Noya Van Delsen dan Mashuri (2013) membandingkan kinerja diagram kontrol $\mathrm{G}$ dengan diagram kontrol Improved $|\mathrm{S}|$.

\subsection{Diagram Kontrol G}

Levinson, Holmes dan Mergen (2002) mengembangkan diagram kontrol multivariat untuk mengontrol variabilitas proses dengan berdasar pada statistik G, yang disebut diagram kontrol G. Levinson, Holmes dan Mergen memperluas statistik G untuk membuat diagram kontrol G. Diagram kontrol G dikhususkan untuk mengontrol variabilitas proses multivariat pada pengamatan subgrup.

Untuk mendeskripsikan diagram kontrol $\mathrm{G}$ dari masing-masing subgrup ke- $m$, dengan ukuran masingmasing subgrup $n$, Levinson, Holmes dan Mergen (2002) mendeskripsikan diagram kontrol G sebagai berrikut:

$$
\mathrm{G}=M \times m=\ln \left[\frac{|S|^{v_{1}+v_{2}}}{\left|S_{1}\right|^{v_{1}}\left|S_{2, i}\right|^{v_{2}}}\right] \times\left(1-\left[\frac{1}{v_{1}}+\frac{1}{v_{2}}-\frac{1}{v_{1}+v_{2}}\right] \times\left[\frac{2 p^{2}+3 p-1}{6(p+1)}\right]\right)
$$

dimana

$$
S_{2, i}=\left[\begin{array}{cccccc}
s_{i, 1}{ }^{2} & s_{i, 12} & \ldots & s_{i, 1 j} & \ldots & s_{i, 1 p} \\
& s_{i, 2} & \ldots & s_{i, 2 j} & \ldots & s_{i, 2 p} \\
& & \ddots & \vdots & \vdots & \vdots \\
& & & s_{i, j}^{2} & \ldots & s_{i, j p} \\
& & & & \ddots & \vdots \\
& & & & & s_{i, p}{ }^{2}
\end{array}\right] ; \begin{gathered}
i=1,2, \ldots, m \\
j=1,2, \ldots, p
\end{gathered}
$$




$$
S_{1}=\left[\begin{array}{cccccc}
\frac{1}{m} \sum_{i=1}^{m} s_{i, 1}{ }^{2} & \frac{1}{m} \sum_{i=1}^{m} s_{i, 12} & \ldots & \frac{1}{m} \sum_{i=1}^{m} s_{i, 1 j} & \ldots & \frac{1}{m} \sum_{i=1}^{m} s_{i, 1} \\
& \frac{1}{m} \sum_{i=1}^{m} s_{i, 2}{ }^{2} & \ldots & \frac{1}{m} \sum_{i=1}^{m} s_{i, 2 j} & \ldots & \frac{1}{m} \sum_{i=1}^{m} s_{i, 2 p} \\
& \ddots & \vdots & \vdots & \vdots \\
& & \frac{1}{m} \sum_{i=1}^{m} s_{i, j}{ }^{2} & \ldots & \frac{1}{m} \sum_{i=1}^{m} s_{i, j p} \\
& & & \ddots & \vdots \\
& & & \frac{1}{m} \sum_{i=1}^{m} s_{i, p}{ }^{2}
\end{array}\right]=\frac{1}{m} \sum_{i=1}^{m} S_{2, i}
$$

dengan,

$$
\begin{aligned}
s_{i, j}{ }^{2} & =\frac{1}{n-1} \sum_{k=1}^{n}\left(x_{i j k}-\bar{x}_{i j}\right)^{2} & s_{i, j j^{*}} & =\frac{1}{n-1} \sum_{k=1}^{n}\left(x_{i j k}-\bar{x}_{i j}\right)\left(x_{i j^{*} k}-\bar{x}_{i j^{*}}\right) ; j \neq j^{*} \\
v_{1} & =m(n-1) & v_{2} & =n-1
\end{aligned}
$$

keterangan

$p \quad=$ Banyaknya karakteristik kualitas

$m \quad$ = Banyaknya subgrup

$n \quad=$ Banyaknya data pada setiap subgrup

$S_{2, i} \quad=$ Matriks kovarian subgrup ke-i

$S_{1} \quad=$ Rata-rata dari matriks kovarian subgrup

$v_{1} \quad=$ Derajat bebas untuk $S_{1}$

$v_{2} \quad=$ Derajat bebas untuk $S_{2, i}$

$s_{i, j}{ }^{2}=$ Variansi variabel ke-j pada subgrup ke- $i$

$S_{i, j j^{*}}=$ Kovariansi antara variabel ke-j dengan variabel ke-j*

$x_{i j k} \quad=$ Merupakan data ke- $k$ variabel ke-j pada subgrup ke- $i$

$\bar{x}_{i j} \quad=$ Merupakan rata-rata variabel ke-j pada subgrup ke- $i$

Menurut Kramer dan Janses (1969) statistik G berdistribusi chi-square dengan derajat kebebasan $\frac{p(p+1)}{2}$. Sehingga diagram kontrol G mengikuti distribusi chi-square dengan derajat kebebasan $\frac{p(p+1)}{2}$. Maka batas kontrol untuk diagram kontrol G adalah :

$$
[L C L, U C L]=\left[\chi_{\frac{p(p+1)}{2}, \frac{\alpha}{2}}^{2}, \chi_{\frac{p(p+1)}{2}, 1-\frac{\alpha}{2}}^{2}\right]
$$

dengan $\alpha$ adalah taraf kepercayaan yang diinginkan. Menurut Levinson, Holmes dan Mergen (2002) jika statistik G yang diperoleh berada di atas UCL atau di bawah LCL, maka dapat disimpulkan proses produksi tidak terkendali.

Diagram kontrol $\mathrm{G}$ digunakan secara khusus untuk mengontrol apakah terjadi perubahan dalam matriks kovarian. Perubahan proses pada matriks kovarian ditunjukkan dengan adanya pengamatan yang berada di luar batas kontrol oleh diagram kontrol G. Sehingga mengakibatkan proses produksi tidak terkontrol. 


\subsection{Diagram Kontrol W}

Variabilitas proses multivariat dapat dinyatakan dalam bentuk matriks kovariansi $\mathrm{S}$ berukuran $p \times p$, dimana elemen diagonal utama merupakan nilai variabilitas dari masing-masing karakteristik kualitas dan elemen selain diagonal utama merupakan nilai kovariansi antar karakteristik kualitas. Terdapat dua komponen yang dapat digunakan untuk mengukur variabilitas total dari sekumpulan data multivariat. Komponen yang pertama adalah determinan matriks kovariansi $(|S|)$ yang biasa disebut dengan generalized variance. Operasi determinan dipilih karena pada operasi determinan selain melibatkan diagonal utama juga melibatkan elemen selain diagonal utama. Akar kuadrat dari komponen pertama ini proporsional dengan luasan atau volume yang dibangkitkan oleh data. Komponen yang kedua adalah trace dari matriks kovariansi $(\operatorname{tr}(S))$ yang merupakan jumlahan dari variabilitas masing-masing karakteristik kualitas.

Diagram kontrol ini dikembangkan oleh Alt pada tahun 1985 dengan mengasumsikan bahwa matriks kovariansi sebenarnya, $\sum$, tidak diketahui (diestimasi dari sampel in control yang besar), perbandingan dibuat antara matriks kovariansi sampel dari proses dan matriks kovariansi yang tidak diketahui. Perbandingan tersebut adalah serangkaian uji signifikansi dalam bentuk sebagai berikut (Alt, 1985):

$$
\begin{aligned}
& H_{0}: \sum=\sum_{0} \\
& H_{1}: \sum \neq \sum_{0}
\end{aligned}
$$

dimana $\sum$ dan $\sum_{0}$ adalah matriks kovariansi populasi dan matriks kovariansi in control. Statistik tersebut adalah rasio dari estimator maximum likelihood untuk distribusi $N_{p}(\vec{\mu}, \Sigma)$ dalam bentuk sebagai berikut :

$$
\begin{gathered}
\Omega=\left\{(\vec{\mu}, \Sigma):-\infty<\vec{\mu}<\infty, \sum \text { adalah definit positif }\right\} \\
\omega=\left\{(\vec{\mu}, \Sigma):-\infty<\vec{\mu}<\infty, \sum=\sum_{0}\right\}
\end{gathered}
$$

Hal ini telah dijelaskan (Anderson, 1984) bahwa estimator maximum likelihood untuk kasus multivariat normal adalah sebagai berikut :

$$
\begin{array}{ll}
\hat{\vec{\mu}}_{\Omega}=\overrightarrow{\bar{x}} & \hat{\Sigma}_{\Omega}=\frac{1}{n} \mathrm{~A}_{i} \\
\hat{\vec{\mu}}_{\omega}=\overrightarrow{\bar{x}} & \hat{\Sigma}_{\omega}=\sum_{0}
\end{array}
$$

dimana $\overrightarrow{\vec{x}}$ adalah vektor mean, $n$ adalah ukuran sampel, dan $\mathrm{A}_{i}=(n-1) \mathrm{S}_{i}$ sehingga fungsi likelihood berdasar pada distribusi normal multivariat adalah

$$
\begin{aligned}
& L(\hat{\Omega})=\left(\frac{2 \pi}{n-1}\right)^{-\frac{p n}{2}}\left|\mathrm{~A}_{i}\right|^{-\frac{n}{2}} e^{-\frac{p n}{2}} \\
& L(\hat{\omega})=(2 \pi)^{\frac{p n}{2}}\left|\sum_{0}\right|^{-\frac{n}{2}} e^{-\frac{1}{2} \operatorname{tr}\left(\sum_{0}^{-1} \mathrm{~A}_{i}\right)}
\end{aligned}
$$

Rasio likelihoodnya adalah sebagai berikut :

$$
\Lambda(x)=\left(\frac{1}{n-1}\right)^{\frac{p n}{2}} e^{\frac{p n}{2}}\left|\sum_{0}^{-1} \mathrm{~A}_{i}\right|^{\frac{n}{2}} e^{-\frac{1}{2} \operatorname{tr}\left(\sum_{0}^{-1} \mathrm{~A}_{i}\right)}
$$

Rasio log likelihoodnya adalah sebagai berikut :

$$
W_{i}=-2 \ln (\Lambda)=-p n+p n \ln (n)-n \ln \left(\left|\sum_{0}^{-1} \mathrm{~A}_{i}\right|\right)+\operatorname{tr}\left(\sum_{0}^{-1} \mathrm{~A}_{i}\right)
$$

Statistik uji tersebut dihitung dan digambarkan untuk setiap sampel ke-i. dimana $i=1,2, \ldots, n$, yang akan 
ditolak jika nilainya lebih dari $\chi_{\left(\alpha, \frac{p(p+1)}{2}\right)}^{2}$. Jika plot nilai $W_{i}$ lebih dari upper control limit (UCL) $\chi_{\left(\alpha, \frac{p(p+1)}{2}\right)}^{2}$, maka proses dapat dikatakan tidak terkontrol.

\subsection{Average Run Length (ARL)}

ARL merupakan rata-rata pengamatan yang harus diplot pada diagram kontrol sebelum sampai terindikasi kondisi out of control. Berdasarkan definisi ini maka ARL berfungsi untuk mengukur efektifitas kinerja diagram kontrol dalam mendeteksi perubahan pada suatu proses. Penentuan ARL dapat dilakukan dengan 3 pendekatan, yaitu integral, simulasi dan Rantai Markov (Wen Lu dan Reynolds, 2001). Nilai ARL terbagi menjadi 2 yaitu $\mathrm{ARL}_{0}$ (ARL in control) dan $\mathrm{ARL}_{1}$ (ARL out of control) dengan rumus sebagai berikut:

$$
\begin{aligned}
& \mathrm{ARL}_{0}=\frac{1}{\mathrm{P}\left(\text { Tolak } \mathrm{H}_{0} \mid \mathrm{H}_{0} \text { benar }\right)}=\frac{1}{\alpha} \\
& \mathrm{ARL}_{1}=\frac{1}{\mathrm{P}\left(\text { Terima } \mathrm{H}_{0} \mid \mathrm{H}_{0} \text { Benar }\right)}=\frac{1}{1-\beta}
\end{aligned}
$$

dengan $H_{0}$ merupakan proses dalam kondisi in control. Sehingga $\alpha$ disebut tipe kesalahan I pada uji hipotesis, yang berarti probabilitas memutuskan bahwa proses dalam kondisi out of control namun kenyataannya proses dalam kondisi in control. Sedangkan $\beta$ adalah tipe kesalahan II pada uji hipotesis, yang berarti probabilitas memutuskan bahwa proses dalam kondisi in control namun pada kenyataannya proses dalam kondisi out of control, sehingga $1-\beta$ adalah probabilitas yang memutuskan bahwa proses dalam kondisi out of control sebagai proses yang out of control. Maka $\mathrm{ARL}_{0}$ dapat diartikan sebagai rata-rata titik pengamatan yang harus diplot sampai ditemukannya pengamatan yang out of control, pada saat proses berada pada kondisi in control. Sedangkan $\mathrm{ARL}_{1}$ dapat diartikan sebagai rata-rata titik pengamatan yang diplot sampai ditemukannya pengamatan yang out of control pada proses dalam kondisi out of control. Nilai ARL yang diperoleh dengan pendekatan hasil simulasi yang didefinisikan sebagai nilai rata-rata Run Length (RL) dari semua replikasi dalam simulasi. RL merupakan jumlah titik pengamatan hingga ditemukannya out of control yang pertama untuk masing-masing replikasi. Sehingga jika nilai ARL yang dihasilkan semakin kecil, maka sampel yang dibutuhkan untuk memberikan sinyal perubahan proses pun semakin kecil atau dengan kata lain semakin kecil nilai ARL maka semakin cepat pula diagram diagram kontrol dapat mendeteksi peubahan proses, sehingga diagram kontrol tersebut semakin efektif untuk mendeteksi perubahan proses.

\section{Hasil dan Pembahasan}

\subsection{Perbandingan Kinerja Diagram Kontrol G dan W Berdasarkan ARL}

Kinerja diagram kontrol dapat diukur dari seberapa cepat diagram kontrol tersebut mendeteksi sinyal out of control. Sinyal out of control dapat dideteksi dengan menggunakan nilai ARL.

Pada penelitian ini akan digunakan karakteristik kualitas $(p)$ sebanyak 2, 3, dan 4, sedangkan ukuran subgrup $(n)$ sebanyak 5 dan 6, serta alfa sebesar 0,0027. Dalam rangka membantu mendeteksi sinyal out of control dibuat skenario untuk melihat kinerja diagram kontrol. Skenario yang dibuat yaitu melakukan pergeseran dalam matriks kovarian. Pergeseran dibuat pada nilai variansi dalam matriks kovarian. Sehingga skenario yang dibuat bergantung banyaknya karakteristik kualitas yang digunakan. Jika karakteristik kualitas yang digunakan sebanyak 2, maka matriks kovarian yang terbentuk berukuran $2 \mathrm{X} 2$, sehingga skenario yang dibuat adalah 2. Jika karakteristik kualitas yang digunakan sebanyak 3, maka matriks kovarian yang terbentuk berukuran $3 \times 3$, sehingga skenario yang dibuat adalah 3. Demikian juga hal ini berlaku untuk karakteristik kulitas sebanyak 4, maka skenario yang digunakan sebanyak 4. 


\subsection{ARL Diagram Kontrol G dan $W$ untuk $p=2$ dan $n=5$ dan 6.}

Berdasarkan hasil simulasi pada Tabel 1, dapat dilihat grafik nilai ARL diagram kontrol $G$ dan diagram kontrol $\mathrm{W}$ untuk $p=2$ dan $n=5$. Baik pada skenario 1 maupun skenario 2, nilai ARL diagram kontrol G lebih kecil dibandingkan nilai ARL diagram kontrol W. Bahkan untuk pergeseran varian yang sangat kecil sekalipun diagram kontrol G sangat baik dalam mendeteksi sinal out of control. Sedangkan untuk diagram kontrol W nilai ARL yang dibutuhkan untuk pergeseran varian yang kecil sangatlah besar. Selain itu grafik nilai ARL diagram kontrol $\mathrm{W}$ yang ditunjukkan juga cenderung menurun tetapi nilai ARL-nya masih lebih besar dibandingkan dengan nilai ARL diagram kontrol G. Ini ditunjukkan dengan interval nilai ARL untuk diagram kontrol $\mathrm{G}$ yang berkisar 1,24 sampai 1,82 untuk skenario 1 dan 1,01 sampai 1,83 untuk skenario 2 . Sedangkan nilai ARL untuk diagram kontrol W berkisar antara 1,7 sampai 12,05 untuk skenario 1 dan 1,13 sampai 12,9 untuk skenario 2 .

Sedangkan untuk $\mathrm{p}=2$ dan $\mathrm{n}=6$ grafik menunjukkan bahwa nilai ARL untuk diagram kontrol $\mathrm{G}$ lebih statis dan lebih kecil dibanding ARL diagram kontrol W. Bahkan untuk pergeseran yang kecil nilai ARL diagram kontrol $\mathrm{G}$ yang dihasilkan jauh lebih kecil dibanding diagram kontrol W. Ini diperlihatkan oleh nilai ARL diagram kontrol $\mathrm{G}$ dan $\mathrm{W}$ yang masing-masing berkisar antara 1,12 sampai 1,72 dan 1,44 sampai 17,79 untuk skenario 1 sedangkan skenario 2 berkisar antara 1 sampai 1,79 dan 1,1 sampai 20,12. Sehingga untuk $\mathrm{p}=2$ dan $\mathrm{n}=6$, dapat disimpulkan bahwa kinerja diagram kontrol $\mathrm{G}$ lebih baik dibanding diagram kontrol $\mathrm{W}$.

Tabel 1. Grafik Nilai ARL Diagram Kontrol G dan W untuk $p=2, n=5$ dan 6

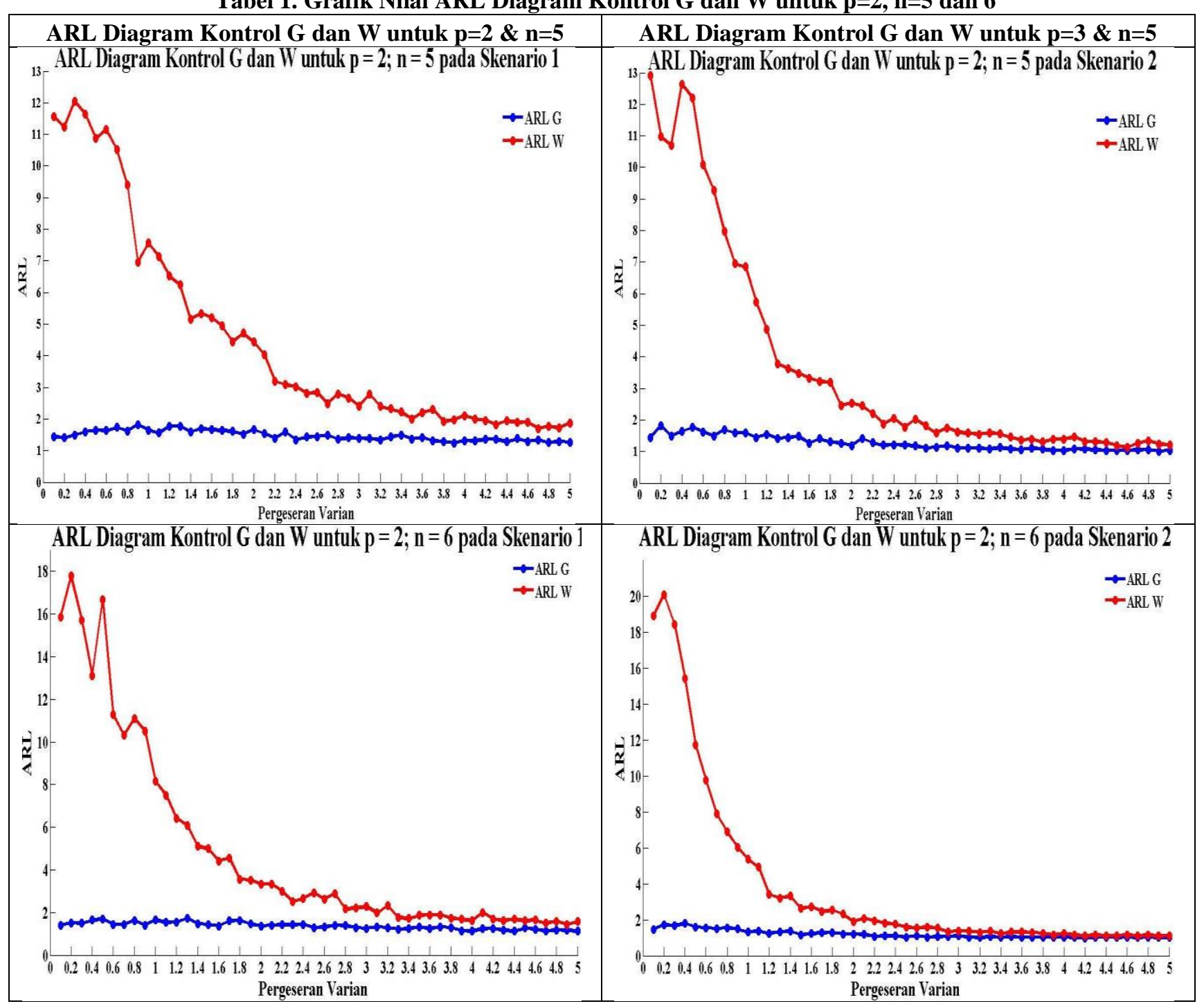




\subsection{ARL Diagram Kontrol $G$ dan $W$ untuk $p=3$ dan $n=5$ dan 6 .}

Pada $\mathrm{p}=3$ dan $\mathrm{n}=5$ akan terdapat 3 skenario, demikian juga untuk $\mathrm{p}=3$ dan $\mathrm{n}=6$ akan terdapat 3 skenario. Dari hasil yang disajikan pada Tabel 2, maka grafik nilai ARL untuk $\mathrm{p}=3$ dan $\mathrm{n}=5$ menunujukkan bahwa digram kontrol $\mathrm{G}$ mengalami fluktuatif dan cenderung menurun. Sedangkan diagram kontrol W cenderung menurun dari pergeseran varian yang kecil ke pergeseran varian yang besar. Selain itu dapat dilihat juga banwa nilai ARL untuk diagram kontrol $\mathrm{G}$ juga lebih kecil dibanding diagram kontrol W. Ini ditunjukkan oleh kisaran nilai ARL untuk diagram kontrol G pada skenario 1, 2 dan 3 adalah 1,29 sampai 1,92; 1,07 sampai 1,93 dan 1,01 sampai 1,92. Sedangkan ARL untuk diagram kontrol W pada skenario 1, 2 dan 3 berkisar antara 1,53 sampai 4,7; 1,11 sampai 5,29 dan 1,04 sampai 4,68. Ini berarti bahwa pada $\mathrm{p}=3$ dan $\mathrm{n}=5$ kinerja diagram kontrol $\mathrm{G}$ lebih baik dibanding kinerja diagram kontrol $\mathrm{W}$. 
Tabel 2. Grafik Nilai ARL Diagram Kontrol $G$ dan $W$ untuk $p=3$, $n=5$ dan 6

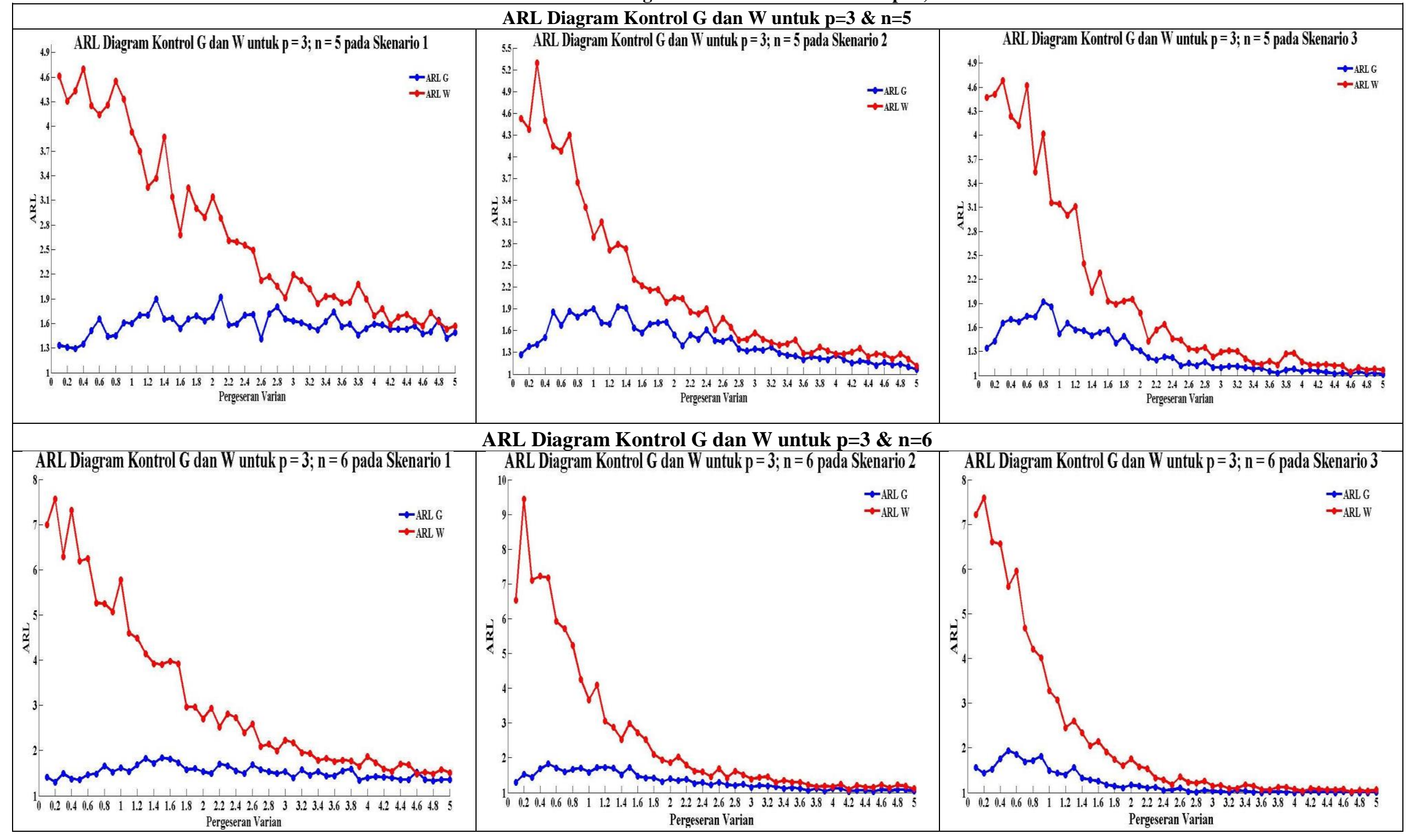


Sedangkan untuk hasil $\mathrm{p}=3$ dan $\mathrm{n}=6$ diperlihatkan juga dalam Tabel 2 , yang menunjukkan nilai-nilai ARL untuk setiap pergeseran varian mempunyai pola yang sama dengan $p=3$ dan $n=5$. Diagram kontrol $G$ mampu dengan cepat mendeteksi pergeseran varian yang kecil, dan grafik nilai ARLnya juga mengalami fluktuatif serta cenderung statis. Sedangkan diagram kontrol W, grafik nilai ARL-nya juga mengalami fluktuatif dan cenderung menurun. Namun untuk pergeseran varian yang kecil, nilai ARL diagram kontrol W sangat besar jika dibanding dengan ARL diagram kontrol G. Selain itu dapat dilihat untuk setiap pergeseran dalam setiap skenario nilai ARL diagram kontrol $G$ lebih kecil dibanding ARL diagram kontrol W. Ini berarti kinerja diagram kontrol $\mathrm{G}$ lebih baik dibanding diagram kontrol $\mathrm{W}$ untuk $\mathrm{p}=3$ dan $\mathrm{n}=6$.

\subsection{ARL Diagram Kontrol G dan $W$ untuk $p=4$ dan $n=5$ dan 6 .}

Hasil dari grafik nilai ARL diagram kontrol $\mathrm{G}$ dan $\mathrm{W} p=4$ dan $\mathrm{n}=5$ dan 6 diperlihatkan pada Tabel 3, dengan jumlah skenario sebanyak 4 untuk $n=5$ dan 4 skenario untuk $n=6$. Berdasarkan hasil untuk $p=4$ dan $\mathrm{n}=5$ yang diperlihatkan pada skenario 1, 2, 3 dan 4, nilai ARL diagram kontrol $\mathrm{G}$ untuk pergeseran varian yang kecil masih lebih kecil dibanding diagram kontrol W. Sedangkan untuk pergeseran varian yang besar, nilai ARL diagram kontrol W masih lebih kecil dibanding ARL diagram kontrol G. Ini diperlihatkan dengan kisaran nilai ARL untuk masing-masing diagram kontrol pada seluruh pergeseran varian. ARL diagram kontrol $G$ pada skenario 1, 2, 3 dan 4 berkisar antara 1,11 sampai 1,86; 1,1 sampai 2,04; 1,05 sampai 1,97 dan 1,01 sampai 1,92. Sedangkan ARL diagram kontrol W berkisar antara 1,25 sampai 2,02 untuk skenario 1; 1,06 sampai 1,98 untuk skenario 2; 1,02 sampai 2,33 untuk skenario 3 dan skenario 4 berkisar 1 sampai 2,16 . Ini berarti pada $p=4$ dan $n=5$ maka kinerja diagram kontrol $\mathrm{G}$ baik jika terjadi pergeseran varian yang kecil, sedangkan jika terjadi pergeseran varian yang besar maka kinerja diagram kontrol W lebih baik dibanding diagram kontrol $\mathrm{W}$.

Hasil diatas berbeda pada grafik nilai ARL diagram kontrol $G$ dan $W$ pada $p=4$ dan $n=6$. Skenario 1 dan 2 dari hasil pada $p=4$ dan $n=6$ sebanding dengan hasil pada $p=4$ dan $n=5$, namun skenario 3 dan 4 memiliki hasil yang bebeda dengan hasil sebelumnya. Pada skenario 1 dan 2 untuk pergeseran varian yang kecil nilai ARL untuk digram kontrol $\mathrm{G}$ lebih kecil dibanding diagram kontrol $\mathrm{W}$, tetapi menghasilkan hasil sebaliknya untuk pergeseran varian yang besar. Sedangkan pada skenario 3 dan 4, khususnya untuk pergeseran varian yang kecil ARL diagram kontrol G lebih kecil dibanding diagram kontrol W. Tetapi pada pergeseran varian yang besar nilai ARL dari kedua diagram hampir sama. Ini menandakan bahwa kinerja diagram kontrol $\mathrm{G}$ sangat baik digunakan jika terjadi pergeseran varian yang kecil, namun untuk pergeseran varian-varian yang besar dapat juga digunakan diagram kontrol $\mathrm{W}$ sebagai pendamping dari diagram kontrol G. 
Tabel 3. Grafik Nilai ARL Diagram Kontrol $G$ dan $W$ untuk $p=4, n=5$ dan 6

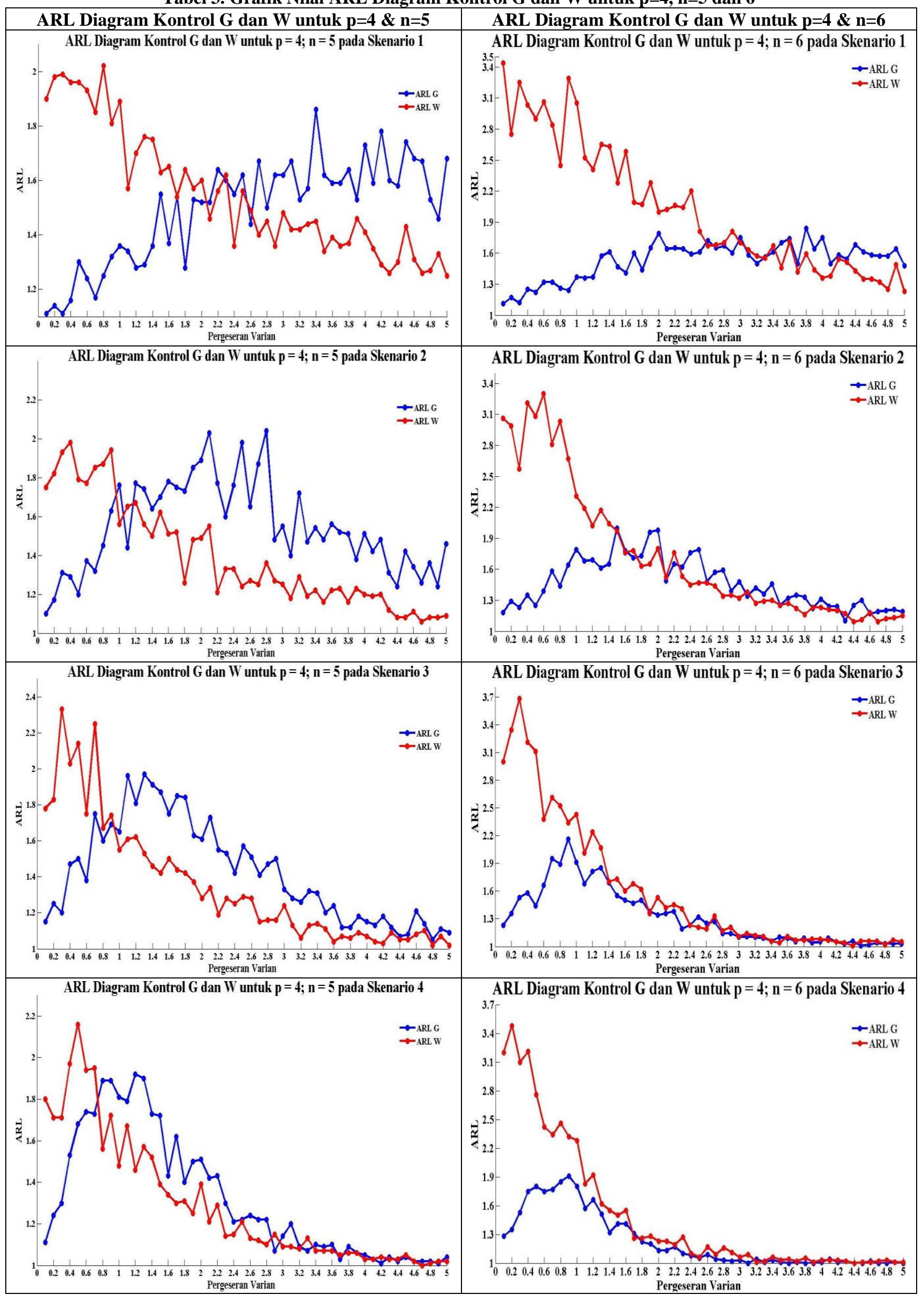




\section{Kesimpulan}

Berdasarkan pembahasan yang telah diuraikan sebelumnya, maka kesimpulan yang dapat diperoleh adalah :

1) Diagram kontrol G sangat baik dalam mendeteksi perubahan proses, walaupun perubahan proses yang terjadi sangat kecil.

2) Diagram kontrol W dapat digunakan sebagai pembanding diagram kontrol G untuk mendeteksi perubahan proses yang besar.

3) Kinerja diagram kontrol $\mathrm{G}$ lebih baik dibanding kinerja diagram kontrol $\mathrm{W}$, namun untuk perubahan proses yang besar diagram kontrol $\mathrm{W}$ dapat digunakan sebagai pendamping diagram kontrol $\mathrm{G}$.

\section{Daftar Pustaka}

[1] F. B. Alt dan S. J. N. E, Multivariate quality control In Encyclopedia of Statistical Scinces Kotz, New York: John Wiley \& Sons, 1985, pp. 110-122.

[2] T. Anderson, An Introduction to Multivariate Statistical Analysis, New York: John Wiley \& Sons, Inc, 1984.

[3] Djauhari, M. A., "Improved Monitoring of Multivariate Process Variability. Journal of Quality Technology," vol. 37, 2005, pp. 32-39.

[4] Kramer, C.Y. dan Jensen, D.R, "Fundamentals of Multivariate Analysis-Part II: Inference About Two Treatments" Journal of Quality Technology, vol. 1, pp. 189-204, 1969.

[5] Levinson, William A., Holmes, D. S. and Mergen, A. E, Variation Chart for Multivariate Processes Quality Engineering, 2002, pp. 539-545.

[6] Montgomery, D. C, "Introduction to Statistical Quality Control," 6th Edition penyunt, New York, John Wiley \& Sons, Inc, 2009.

[7] Noya Van Delsen, M dan Mashuri, M, "Perbandingan Kinerja Diagram Kontrol G dan Diagram Kontrol Improved $|\mathrm{S}|$, , Surabaya.

[8] Rakhmawati, Dwi Yuli, "Perbandingan Kinerja Diagram Kontrol Multivariat untuk Variabilitas Berdasarkan Matriks Kovariansi dan Matriks Korelasi," Surabaya, 2011.

[9] Sindelar, M.F, "Multivariate Statistical Process Control For Corellation Matrices," Tesis Ph.D, 2007.

[10] Wen Lu, C. dan Reynolds, M. R, “Cususm Charts for Monitoring an Autocorrelated Process," Journal of Quality Technology, pp. 316-334., 2001. 